\title{
Evaluation of groundwater quality in Dongula basin: the Northern state of Sudan
}

\author{
H. M. A. M. Omer \\ Department of Laboratories, Ministry of Water Resources, Sudan
}

\begin{abstract}
The purpose of this paper is to evaluate the quality and chemical features of groundwater in the Dongola basin, Northern State, Sudan. The majority of water samples were moderately hard water, and temporarily hard - carbonate and bicarbonate hardness. The dominant anion is carbonate and bicarbonate $\left(\mathrm{CO}_{3}^{--}\right.$, $\mathrm{HCO}_{3}{ }^{-}$); and the dominant cation is sodium on the west side of the river (water type - Trona rocks). The majority of water samples taken at the west river bank were (sodium-calcium-magnesium)-(bicarbonate-sulphate) type, while at the east river bank, the majority was (sodium-calcium-magnesium)-(bicarbonate) type. (Sulphate-chloride) type was found for samples taken at the two banks of the river while (sulphate) and (chloride) types were found only in samples taken at the west bank.

Keywords: Sudan, Northern State, Dongula, Dongula basin, River Nile, groundwater water types.
\end{abstract}

\section{Introduction}

The hydrological structure of the Dongola Basin is considered to be one of the most important groundwater basins in Sudan in terms of groundwater availability, water quality and degree of utilization. The basin is considered as the northern extension of the Blue Nile-Khartoum rift basin. Groundwater occurs in the sandstone layers of the Wadi El Melek formation and, to a lesser extent, in the Wadi Howar formation and the sandy lenses of the river deposits. Depth to groundwater is controlled by topography, basement configuration, proximity to the River Nile, as well as the existing pumping regime [1]. The groundwater reflects the mineralogical composition of the rocks in the aquifer and also can be used to localize recharge areas and to determine the origin of 
groundwater (meteoric, marine, fossil, or water) and of individual chemical components (e.g. carbonate, sulphate, nitrate and ammonium). The water compositions can also give information about the processes of water-rock interaction and microbial processes in the water chemical precipitation controlled by the solubility of a substance, and chemical alteration by, for example, oxydoreduction and complexation processes. Cations in the water types came mainly from the leaching of the rock minerals and the soil whereas the anions came mainly from lithological sources.

\section{Location and accessibility}

The study area lies along the River Nile in the Northern State. The area forms an elongated shape and is generally bounded by longitudes $\left(29^{\circ} .8000-31^{\circ} .9200 \mathrm{E}\right.$ and latitudes $17^{\circ} .1900-20^{\circ} .2100 \mathrm{~N}$ (Fig. 1).

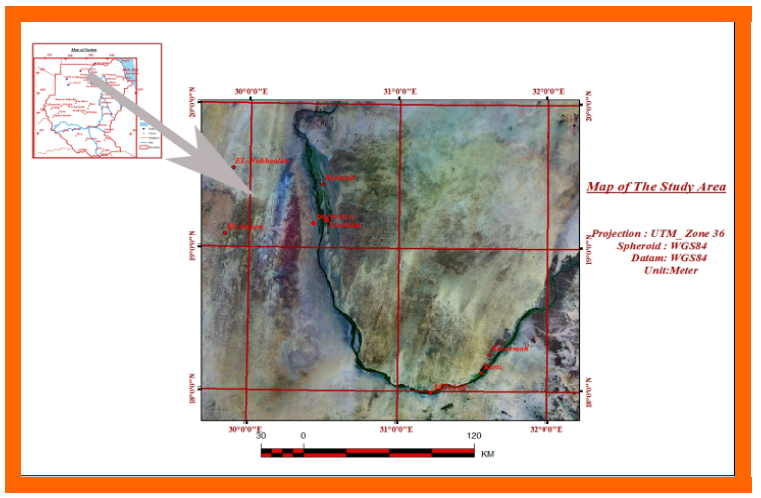

Figure 1: $\quad$ Location of the study area.

\subsection{Drainage system/(s) - The River Nile}

The River Nile is the most important source of water for irrigation; about $800^{*} 10^{6} \mathrm{~m}^{3}$ yearly. It is the only perennial surface water resource available in this area. High water levels occur during the high flood period (AugustSeptember) and the minimum water level during December and June; the difference between the highest and lowest level is about $4.59 \mathrm{~m}$ at Dongola [2].

\subsection{Climate and vegetation}

The area lies in the arid desert climatic region, in which rainfall is very low or negligible. The winter season is distinctly pleasant; from October to mid March the mean daily temperature is below $20^{\circ} \mathrm{C}$. In the early morning the temperature may fall to zero $\left(0^{\circ} \mathrm{C}\right)$, humidity is low, and there is very little cloud cover and no rain [3]. The wind blows from the north with a mean speed of between 15 and $20 \mathrm{Km} / \mathrm{h}$. Summer is long and very hot - from the beginning of May until the end of September, the mean daily temperature reaches $40^{\circ} \mathrm{C}$; humidity is high 
particularly in August, and the normal wind speed falls about $12 \mathrm{Km} / \mathrm{h}$; and blows from different directions [4]. The mean annual rainfall is about $9.280 \mathrm{~mm}$ /annum (Fig. 2 - 1989-2008), rainfall characterized by low variability 17.1223 is as shown in Table 1. Vegetation in the study area is restricted to the banks of the River Nile and the floors of the big seasonal water resources such as Wadi ElMeilk, Wadi Al-Mugaddam, Khor Abu Sunt and Khor Masur. In these stream beds, coarse grasses and Acacia tortilis, Acacia mellifera and Acacia seyal are found. Along both sides of the Nile date palms are intensively farmed. Some isolated trees of Sidr (Ziziphrusspina), Haraz Acacia albida and some Green Nile grasses are also found. Herbs and fine grasses spring up after very rare rain showers during the summer but they soon disappear [5].

Table 1: $\quad$ Annual rainfall variability at Dongola.

\begin{tabular}{|c|c|c|c|}
\hline Lowest $(\mathrm{mm})$ & Highest $(\mathrm{mm})$ & Average rainfall $(\mathrm{mm})$ & Standard deviation \\
\hline 0.0 & 74.2 & 9.280 & 17.1223 \\
\hline
\end{tabular}

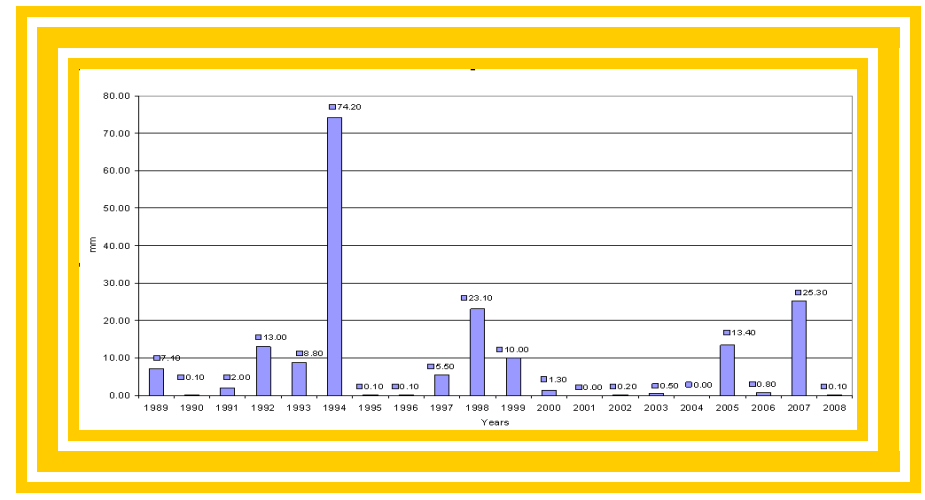

Figure 2: $\quad$ Dongula annual average rainfall 1989-2008.

\subsection{Geology of the study area}

Nubian formation, Wadi El-Melek formation, superficial deposit and basement complex [9].

\subsection{Hydrology of the study area}

Dongola Sub-Basin;

El- Debba Sub-Basin;

Wadi EL-Mugaddam Sub-Basin.

\section{Statement of the problem}

Water quality has become one of the important issues for socioeconomic development in all countries; the determination of chemical quality of water 
becomes problematic in developing countries like Sudan. Many places contain saline water aquifers or are subjected to mix or interaction by saline water. Salts can be introduced either through complicated chemical processes or by simple addition or mixing from a surface or subsurface saline source. One or many processes may contribute. Regarding this problem, this study will concentrate on salinity problems, the source of saline water, which in specific aquifers, in relation with other water bodies either surface or groundwater, the chemical characteristic of groundwater at the two sides of the river, will be statistically treated to see whether there are significant differences or not.

\section{Sampling and analytical procedure}

131 and 139 water samples were taken from boreholes on the River Nile at the two sides for chemical analysis (major anions and cations). By using the standard methods (Fig. 3), the physico-chemical parameters were measured in the field (EC, $\mathrm{pH}$ and TDS); also TDS was measured in the lab. By the dryness method, carbonate, bicarbonate, chloride, calcium, magnesium total hardness and total alkalinity were measured by titrations method; sulphate, nitrate, nitrite ammonia were measured by spectrometric method.

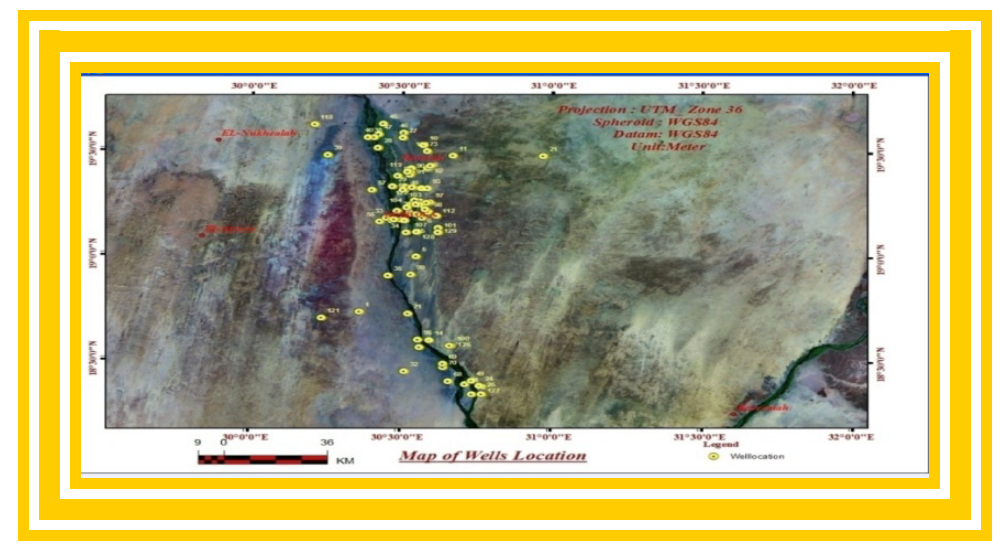

Figure 3: Location of water samples in the study area.

\section{Results and discussion}

$95.86 \%$ of existing groundwater sources at the east river bank and $91.6 \%$ at the west river bank have TDS less than $1000 \mathrm{ppm}$. All of them represent fresh water, according to classifications of water after Corell $1985[6,11]$ the range from 0 100ppm.TDS. Also TDS-EC relationship (= geochemical coefficients).

East river bank and west river bank - demonstrated by Figures 4 and 5 - were 0.6826 (east side) and 0.7066 (west side); the coefficients at the two sides are the same when it becomes to one decimal $(0.7)$. About $4 \%$ of east river bank water and $8 \%$ of west river bank water represents brackish water. Because there 


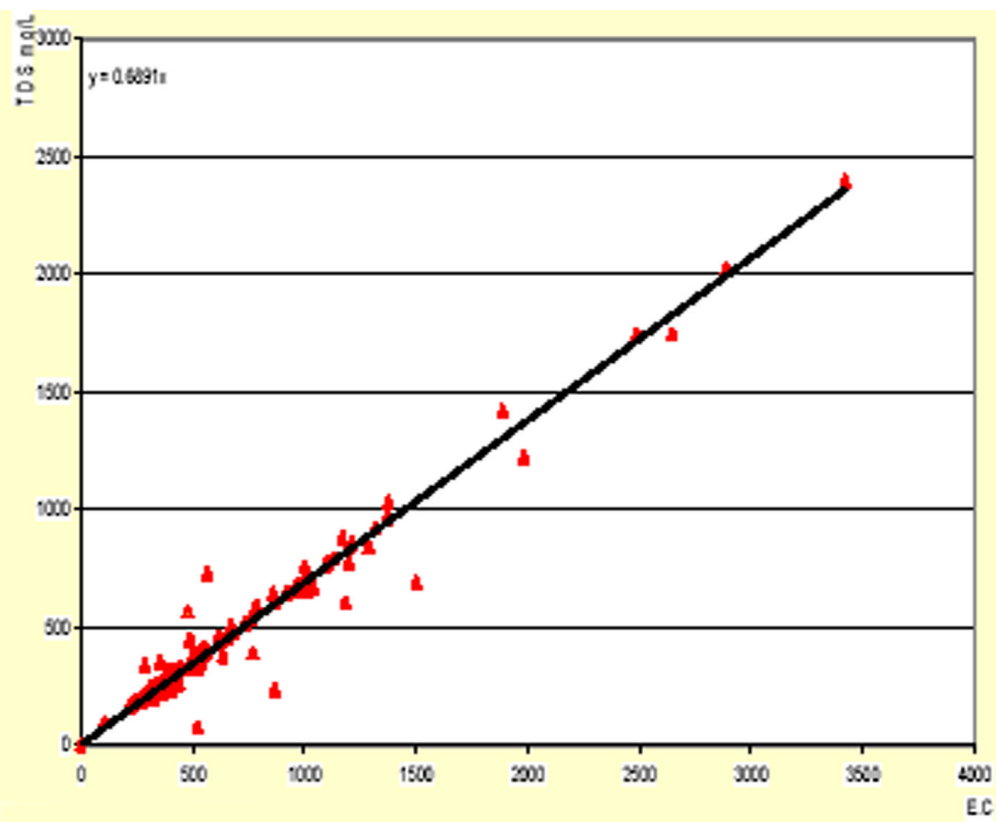

Figure 4: TDS vs. EC in the study area, east river bank.

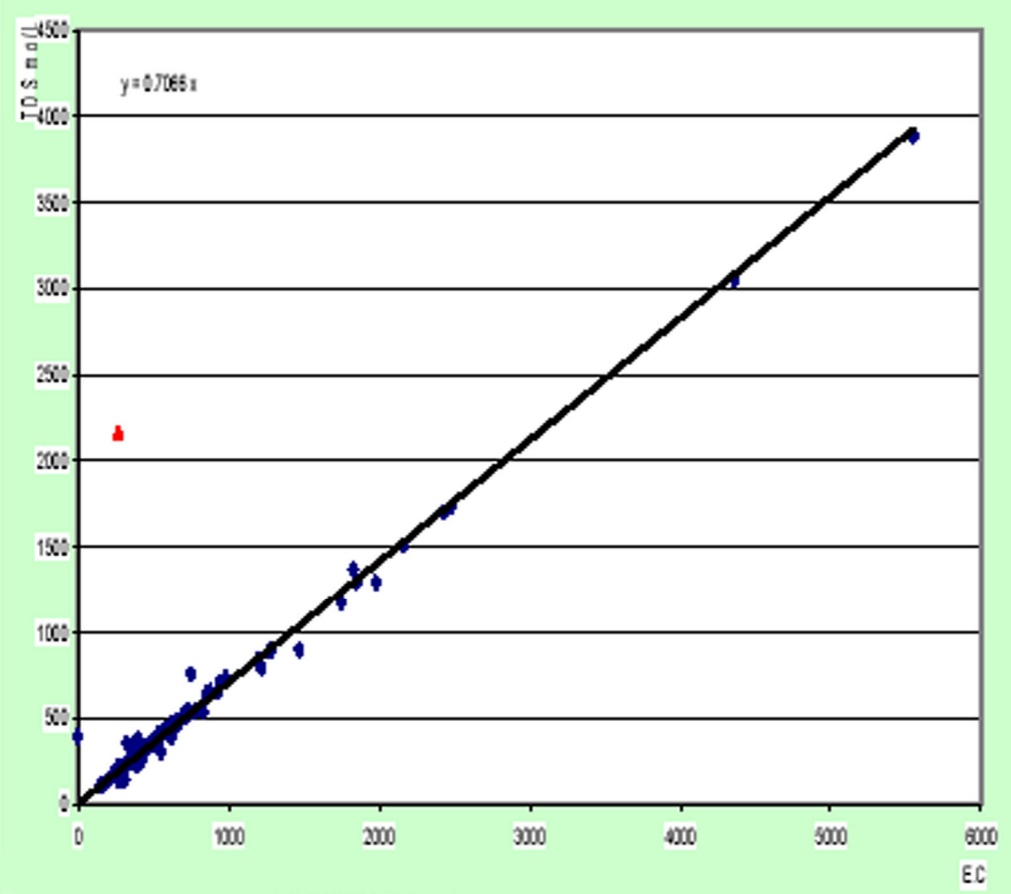

Figure 5: TDS vs. EC in the study area, west river bank. 
are seven samples at the west river bank that had values greater than the standards (1001-10000 mg/l) their concentrations were as follows: $2160 \mathrm{mg} / \mathrm{l}$, $1701,1512,1736,3885,3052$ and $3052 \mathrm{mg} / 1$ those are for samples 2, 62, 66, 75, 109, 117 and 119 respectively; the high concentrations of TDS in the open and shallow wells are due to evaporation and in the deep wells are due to leaching of rocks and concentration of chemical ions in the aquifer.

\section{Suitability for drinking}

There were some water samples at the east river bank which were unsuitable for human consumption because there were one or more parameters greater than WHO and Sudanese Level standards. For example, sample No. 75 with high concentrations of sodium and chloride, this water resembles a feature of sea water $(\mathrm{NaCl})$. Sample No. 44 recorded high calcium, magnesium chloride, and sulphate concentrations. Then there were $\mathrm{CaCl}_{2} \mathrm{MgCl}_{2}-\mathrm{CaSO}_{4}-\mathrm{MgSO}_{4}$ rocks type in the locations. The majority of water samples were moderately hard water, and temporarily hard (carbonate and bicarbonate hardness). It is to be assumed that groundwater having $\mathrm{pH}$ values above 8.4 are usually associated with sodium carbonate-bicarbonate water; moderately high $\mathrm{pH}$ values are commonly associated with high bicarbonate concentrations. Also, we can say the main rocks in the aquifer are calcium and magnesium carbonate and bicarbonate type (dolomite). The other type of hardness is the permanent hardness (sulphate, chloride, salts). Magnesium ion concentration at east river bank varied from $0 \mathrm{mg} / \mathrm{l}$ to $167 \mathrm{mg} / \mathrm{l}$. All samples were within the WHO range except for sample No. $44(167 \mathrm{mg} / \mathrm{l})$. At the west river bank the minimum concentration was $0 \mathrm{mg} / \mathrm{l}$ (sample No. 37) but there were three samples with values greater than standards (samples Nos. 75, 117 and 119). It is to be anticipated that the chemical composition of aquifer rocks is void of magnesium ion, or constituents of water may become modified by subsequent chemical reactions, such as cation exchange, absorption of dissolved ions and biological influences. Also, according to my point of view, high magnesium concentration is related to high dolomite minerals if calcium ions are found in the aquifer. The maximum concentration of calcium ions in the water samples at both west and east banks at the study area is $120 \mathrm{mg} / \mathrm{l}$ : The similarities of concentration are due to simulations of chemical composition of calcium ions in the rocks. It is possible that the same rocks or basalts maybe among the igneous rocks and in carbonate rocks (limestone, dolostone) among sedimentary rocks. Calcium is also a dominant cation in most river waters.

Sodium ion concentrations of groundwater samples taken in the study area were $0 \mathrm{mg} / 1 \mathrm{Na}^{+}$at the west bank samples 2, 10 and 11 . Here it may be that the chemical composition of aquifer rocks at these wells is without sodium, like anhydrites, calcium carbonate, dolomite and sylivite. As for sample 119, the concentration of sodium is $1537 \mathrm{mg} / \mathrm{l}$ and the concentration of bicarbonate is $285 \mathrm{mg} / \mathrm{l}$ so the water type at this well is sodium bicarbonate water having $\mathrm{pH}$ values above 8.4. Also high sodium with high chloride suggests solution of halite; if considerable sulphate and calcium are also present. 
Table 2: $\quad$ The drinking water problems of the study area - east river bank.

\begin{tabular}{|l|l|l|l|l|l|}
\hline Parameters & \multicolumn{2}{|c|}{$\begin{array}{r}\text { Within the range of } \\
\text { WHO standard }\end{array}$} & \multicolumn{2}{|c|}{ Greater than WHO range } \\
\hline & Wells & \multicolumn{1}{|c|}{$\%$} & Wells & $\%$ & Remarks \\
\hline $\mathrm{pH}$ & 94 & 67.63 & 45 & 32.37 & Many samples over the range. \\
\hline TDS & 135 & 97.83 & 3 & 2.17 & $75,81,102$ and 122 \\
\hline $\mathrm{TH}$ & 136 & 98.55 & 2 & 1.45 & 44 and $102 ; 122$ \\
\hline $\mathrm{K}^{+}$ & 139 & 100 & - & - & All samples within the WHO range \\
\hline $\mathrm{Na}^{+}$ & 133 & 95.68 & 6 & 4.32 & $75,77,81,85,133$ and 135 \\
\hline $\mathrm{Ca}^{++}$ & 135 & 97.12 & 4 & 2.88 & $44,102,122$ and 133 \\
\hline $\mathrm{Mg}^{++}$ & 138 & 99.28 & 1 & 0.72 & 44 \\
\hline $\mathrm{Cl}^{-}$ & 135 & 97.12 & 4 & 2.88 & $44,75,81$ and 102 \\
\hline $\mathrm{SO}_{4}=$ & 129 & 92.81 & 10 & 7.19 & $27,44,77,81,93,102,121,122,133$ and 138 \\
\hline $\mathrm{F}^{-}$ & 138 & 99.28 & 1 & 0.72 & 27 has 2 mg/l \\
\hline $\mathrm{NH}_{3}$ & 139 & 100 & 0 & 0 & All samples within the WHO range \\
\hline $\mathrm{NO}_{2-}$ & 139 & 100 & 0 & 0 & All samples within the WHO range \\
\hline $\mathrm{NO}_{3-}$ & 139 & 100 & 0 & 0 & All samples within the WHO range \\
\hline
\end{tabular}

Table 3: The drinking water problems of the study area - west river bank.

\begin{tabular}{|c|c|c|c|c|c|c|}
\hline \multirow[t]{2}{*}{ Parameters } & \multicolumn{2}{|c|}{$\begin{array}{c}\text { Within the range of } \\
\text { WHO Std. }\end{array}$} & \multicolumn{3}{|c|}{ Greater than WHO range } & \multirow[t]{2}{*}{ WHO std. } \\
\hline & Wells & $\%$ & Wells & $\%$ & Remarks & \\
\hline $\mathrm{pH}$ & 94 & 71.76 & 37 & 28.24 & About $30 \%$ of samples & $6.5-8.5$ \\
\hline TDS & 124 & 94.66 & 7 & 5.34 & $2,62,66,75,117$ and 119 & $1000 \mathrm{mg} / \mathrm{l}$ \\
\hline $\mathrm{TH}$ & 127 & 96.95 & 4 & 3.05 & $75,98,100$ and 119 & \\
\hline $\mathrm{K}$ & 130 & 99.24 & 1 & 0.76 & 66 & \\
\hline $\mathrm{Na}$ & 121 & 92.37 & 10 & 7.63 & Ten samples & \\
\hline $\mathrm{Ca}$ & 125 & 95.42 & 6 & 4.58 & Six samples & \\
\hline $\mathrm{Mg}^{++}$ & 128 & 97.71 & 3 & 2.29 & 75,117 and 119 & \\
\hline $\mathrm{Cl}^{-}$ & 123 & 93.89 & 8 & 6.11 & $59,66,72,75,109,112,1179$ & \\
\hline $\mathrm{SO}_{4}=$ & 118 & 90.08 & 13 & 9.92 & Thirteen samples & \\
\hline Fluoride & 126 & 96.18 & 4 & 3.82 & $23,117,118$ and 119 & $1.5 \mathrm{mg} / 1$ \\
\hline $\mathrm{NH}_{3}$ & 131 & 100 & 0 & 0 & No sample & \\
\hline $\mathrm{NO}_{2-}$ & 131 & 100 & 0 & 0 & No sample & \\
\hline $\mathrm{NO}_{3-}$ & 131 & 100 & 0 & 0 & No sample & \\
\hline
\end{tabular}


The variations of sulphate ion concentrations in the study area maybe due to sedimentary in evaporates comprising gypsum $\left(\mathrm{CaSO}_{4} \cdot 2 \mathrm{H}_{2} \mathrm{O}\right)$ or unhydrite $\left(\mathrm{CaSO}_{4}\right)$. Ion concentrations in the study area varied from $0 \mathrm{mg} / \mathrm{l}$ to $2 \mathrm{mg} / \mathrm{l}$ (WHO $1.5 \mathrm{mg} / \mathrm{l})$

All groundwater samples at the east side were suitable for livestock (because the quality factors of all of them are within the range of the Guidelines of the California Control Board (1963), while at the west side there were three water samples unsuitable for livestock because the quality factor of bicarbonate was above $500 \mathrm{mg} / \mathrm{l}$.

\section{Suitability for livestock}

Table 4: $\quad$ The Guidelines of the California Control Board (1963).

\begin{tabular}{|c|c|c|c|c|}
\hline Quality & Threshold & Limiting & \multicolumn{2}{|c|}{ Maximum Conc ${ }^{\mathrm{n}}$ in the study area } \\
\hline & & & East river bank & West river bank \\
\hline TDS & 2500 & 5000 & 2394 mg/L (No. 81) & 3885mg/L (No. 109 \\
\hline $\mathrm{Ca}^{++}$ & 500 & 1000 & $120 \mathrm{mg} / \mathrm{L}$ (No.122) & 149mg/L. (Nos. 117, 119) \\
\hline $\mathrm{Mg}^{++}$ & 250 & 500 & 167 mg/L (No. 44) & 196mg/L (Nos. 117, 119) \\
\hline $\mathrm{Na}^{+}$ & 1000 & 2000 & $524 \mathrm{mg} / \mathrm{L}$ (No.81) & 1553.7 (No. 110) \\
\hline $\mathrm{HCO}_{3}^{-}$ & 500 & 500 & $469 \mathrm{mg} / \mathrm{L}$ (No. 86) & 1464mg/L (No. 130) \\
\hline $\mathrm{Cl}^{-}$ & 1500 & 3000 & $550 \mathrm{mg} / \mathrm{L}$ (No.81) & 1314mg/L (No. 109) \\
\hline $\mathrm{SO}_{4}{ }^{=}$ & 500 & 1000 & 387 mg/L (No.133) & 1225mg/L (No. 109) \\
\hline
\end{tabular}

Table 5: $\quad$ Irrigation problems in the study area, east river bank.

\begin{tabular}{|c|c|c|c|c|c|c|c|}
\hline \multirow{2}{*}{\multicolumn{2}{|c|}{ Irrigation problems }} & \multicolumn{2}{|c|}{ No problems } & \multicolumn{2}{|c|}{ Increasing problems } & \multicolumn{2}{|c|}{$\begin{array}{l}\text { Severe } \\
\text { problems }\end{array}$} \\
\hline & & Wells & $\%$ & Wells & $\%$ & Wells & $\%$ \\
\hline \multicolumn{2}{|l|}{ Salinity } & 100 & 71.94 & 37 & 26.62 & 2 & 1.44 \\
\hline Permeability & Adj. SAR & 5 & 3.60 & 12 & 8.62 & 122 & 87.78 \\
\hline \multirow{2}{*}{$\begin{array}{l}\text { Specific Ion } \\
\text { Toxicity }\end{array}$} & Adj. SAR & 5 & 3.60 & 12 & 8.62 & 122 & 87.78 \\
\hline & $\mathrm{Cl}^{-}$ & 125 & 89.93 & 11 & 7.91 & 3 & 2.16 \\
\hline \multirow[t]{3}{*}{ Miscellaneous } & $\mathrm{NO}_{3}{ }^{-}$ & 88 & 63.31 & 49 & 35.25 & 2 & 1.44 \\
\hline & $\mathrm{HCO}_{3}^{-}$ & 5 & 3.60 & 133 & 96.68 & 1 & 0.72 \\
\hline & $\mathrm{pH}$ & 0 & 0 & 0 & 0 & 139 & 100 \\
\hline
\end{tabular}




\section{Suitability for irrigation}

Most water samples in the study area indicated that there were no salinity problems; TDS values within the WHO and SLS (1500 mg/l, fresh water) also electrical conductivity (EC) measurements in $\mathrm{mmhos} / \mathrm{cm}$ varied within the permissible range $(<0.75)$. All water samples in the study area can be used for different types of irrigation according to the classification mentioned above for suitability for irrigation.

Table 6: $\quad$ Irrigation problems in the study area, west river bank).

\begin{tabular}{|l|l|l|l|l|l|l|l|}
\hline \multicolumn{2}{|c|}{ Irrigation problems } & \multicolumn{2}{c|}{ No problems } & \multicolumn{2}{c|}{ Increasing problems } & \multicolumn{2}{c|}{ Severe problems } \\
\cline { 3 - 9 } & & Wells & $\%$ & Wells & $\%$ & Wells & $\%$ \\
\hline Salinity & 105 & 802 & 23 & 17.6 & 3 & 2.29 \\
\hline Permeability & Adj. SAR & 118 & 90.1 & 7 & 5.3 & 6 & 4.58 \\
\hline $\begin{array}{l}\text { Specific Ion } \\
\text { Toxicity }\end{array}$ & Adj. SAR & 103 & 78.6 & 22 & 16.8 & 6 & 4.58 \\
\cline { 2 - 9 } & $\mathrm{Cl}^{-}$ & 121 & 92.4 & 7 & 5.3 & 3 & 2.29 \\
\hline \multirow{3}{*}{ Miscellaneous } & $\mathrm{NO}_{3}^{-}$ & 74 & 56.5 & 55 & 42 & 2 & 1.53 \\
\cline { 2 - 9 } & $\mathrm{HCO}_{3}^{-}$ & 7 & 5.3 & 121 & 92.37 & 3 & 2.29 \\
\cline { 2 - 9 } & $\mathrm{pH}$ & 0 & 0 & 0 & 0 & 131 & 100 \\
\hline
\end{tabular}

On the two sides of the river there were three dominant anion water types divided as follows:

$$
\begin{array}{ll}
1- & \left(\mathrm{HCO}_{3}+\mathrm{CO}_{3}\right) \text { type } \\
2- & \left(\mathrm{HCO}_{3}+\mathrm{CO}_{3}\right)-\left(\mathrm{SO}_{4}-\mathrm{Cl}\right) \text { type } \\
3- & \left(\mathrm{SO}_{4}-\mathrm{Cl}\right) \text { type }
\end{array}
$$

East side was dominated by:

1- $\left(\mathrm{HCO}_{3}+\mathrm{CO}_{3}\right)$ type, included the majority of samples. This water type is divided into the following subgroups: (Piper Diagram (Fig. 6) showed bicarbonate water type).

- $\quad(\mathrm{Na}+\mathrm{K})-\left(\mathrm{HC} \mathrm{O}_{3}+\mathrm{CO}_{3}\right)$ type

- $\quad(\mathrm{Na}+\mathrm{K})+(\mathrm{Ca}+\mathrm{Mg})-\left(\mathrm{HC} \mathrm{O}_{3}+\mathrm{CO}_{3}\right)$ type

- $\quad(\mathrm{Ca}+\mathrm{Mg})-\left(\mathrm{HC} \mathrm{O}_{3}+\mathrm{CO}_{3}\right)$ type

2- $\left(\mathrm{HCO}_{3}+\mathrm{CO}_{3}\right)+\left(\mathrm{SO}_{4}-\mathrm{Cl}\right)$ type includes only one subgroup (Fig. 7).

- $\quad(\mathrm{Na}+\mathrm{K})-\left(\mathrm{HCO}_{3}+\mathrm{CO}_{3}\right)+\left(\mathrm{SO}_{4}-\mathrm{Cl}\right)$ type

3- This group was dominated by $\left(\mathrm{SO}_{4}-\mathrm{Cl}\right)$ type; was divided into the following subgroups (Fig. 8).

- $\quad(\mathrm{Na}+\mathrm{K})-\left(\mathrm{SO}_{4}-\mathrm{Cl}\right)$ type 


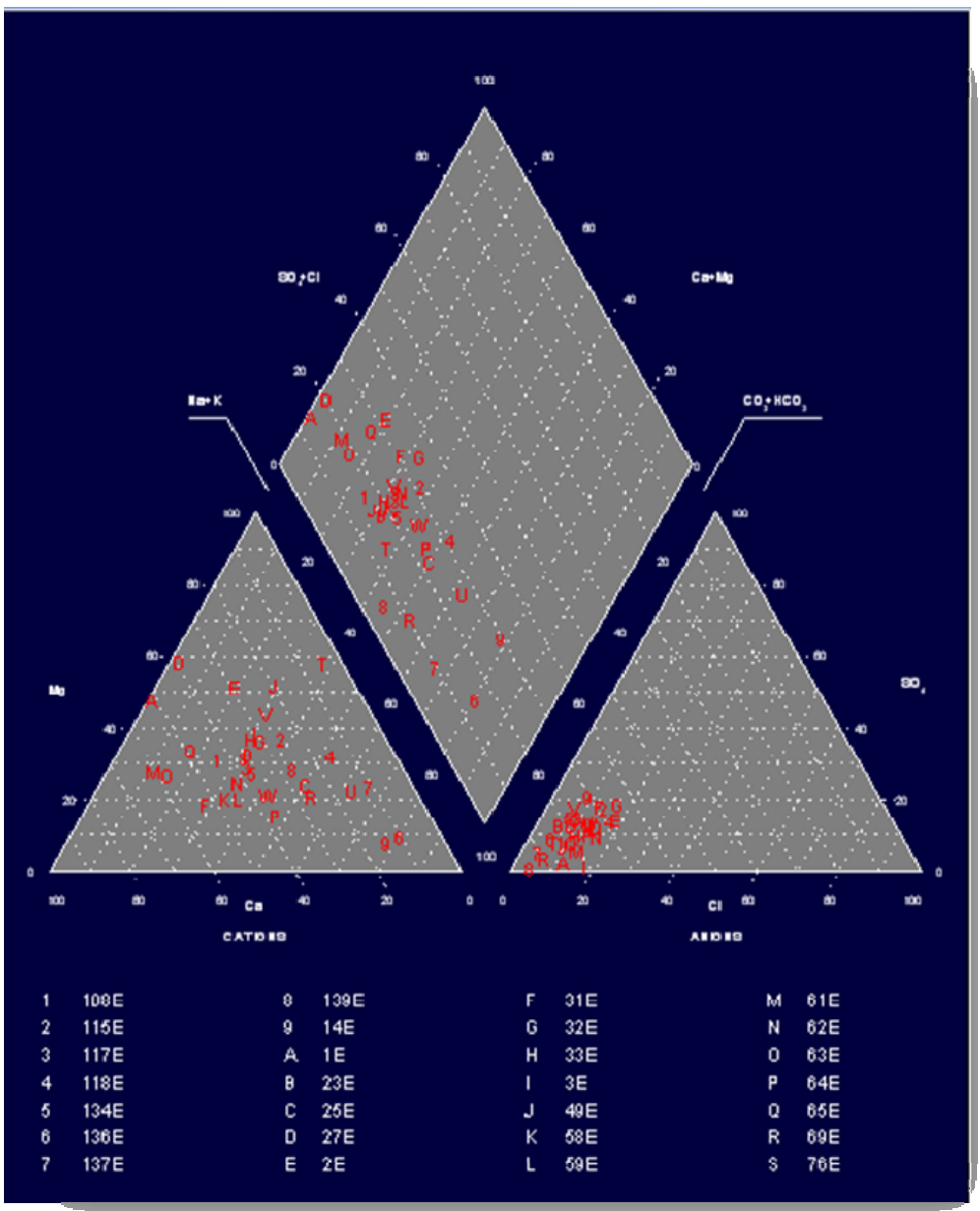

Figure 6: Bicarbonate water type east side of the river.

While the west side of the river, dominated by $\left(\mathrm{HCO}_{3}+\mathrm{CO}_{3}\right)$ type, included the majority of samples, this water type is divided into the following subgroups: (Piper Diagram (Fig. 9) showed bicarbonate water type).

- $\quad(\mathrm{Na}+\mathrm{K})-\left(\mathrm{HCO}_{3}+\mathrm{CO}_{3}\right)$ type

- $\quad(\mathrm{Na}+\mathrm{K})+(\mathrm{Ca}+\mathrm{Mg})-\left(\mathrm{HCO}_{3}+\mathrm{CO}_{3}\right)$ type

- $\quad(\mathrm{Ca}+\mathrm{Mg})-\left(\mathrm{HCO}_{3}+\mathrm{CO}_{3}\right)$ type

2- Dominated by $\left(\mathrm{HCO}_{3}+\mathrm{CO}_{3}\right)+\left(\mathrm{SO}_{4}-\mathrm{Cl}\right)$ type, it includes two subgroups (Fig. 10)

- $\quad \mathrm{Na}+\mathrm{K})+(\mathrm{Ca}+\mathrm{Mg})-\left(\mathrm{HCO}_{3}+\mathrm{CO}_{3}\right)+\left(\mathrm{SO}_{4}-\mathrm{Cl}\right)$ type

- $\quad(\mathrm{Ca}+\mathrm{Mg})-\left(\mathrm{HCO}_{3}+\mathrm{CO}_{3}\right)+\left(\mathrm{SO}_{4}-\mathrm{Cl}\right)$ type 
3- This group, dominated by the $\left(\mathrm{SO}_{4}-\mathrm{Cl}\right)$ type, was divided into the following subgroups (Fig. 11).

$$
\begin{array}{ll}
\text { - } & \left((\mathrm{Na}+\mathrm{K})-\left(\mathrm{SO}_{4}-\mathrm{Cl}\right)\right. \text { type } \\
\text { - } & (\mathrm{Na}+\mathrm{K})+(\mathrm{Ca}+\mathrm{Mg})\left(\mathrm{SO}_{4}-\mathrm{Cl}\right) \text { type } \\
\text { - } & (\mathrm{Ca}+\mathrm{Mg})\left(\mathrm{SO}_{4}-\mathrm{Cl}\right) \text { type }
\end{array}
$$

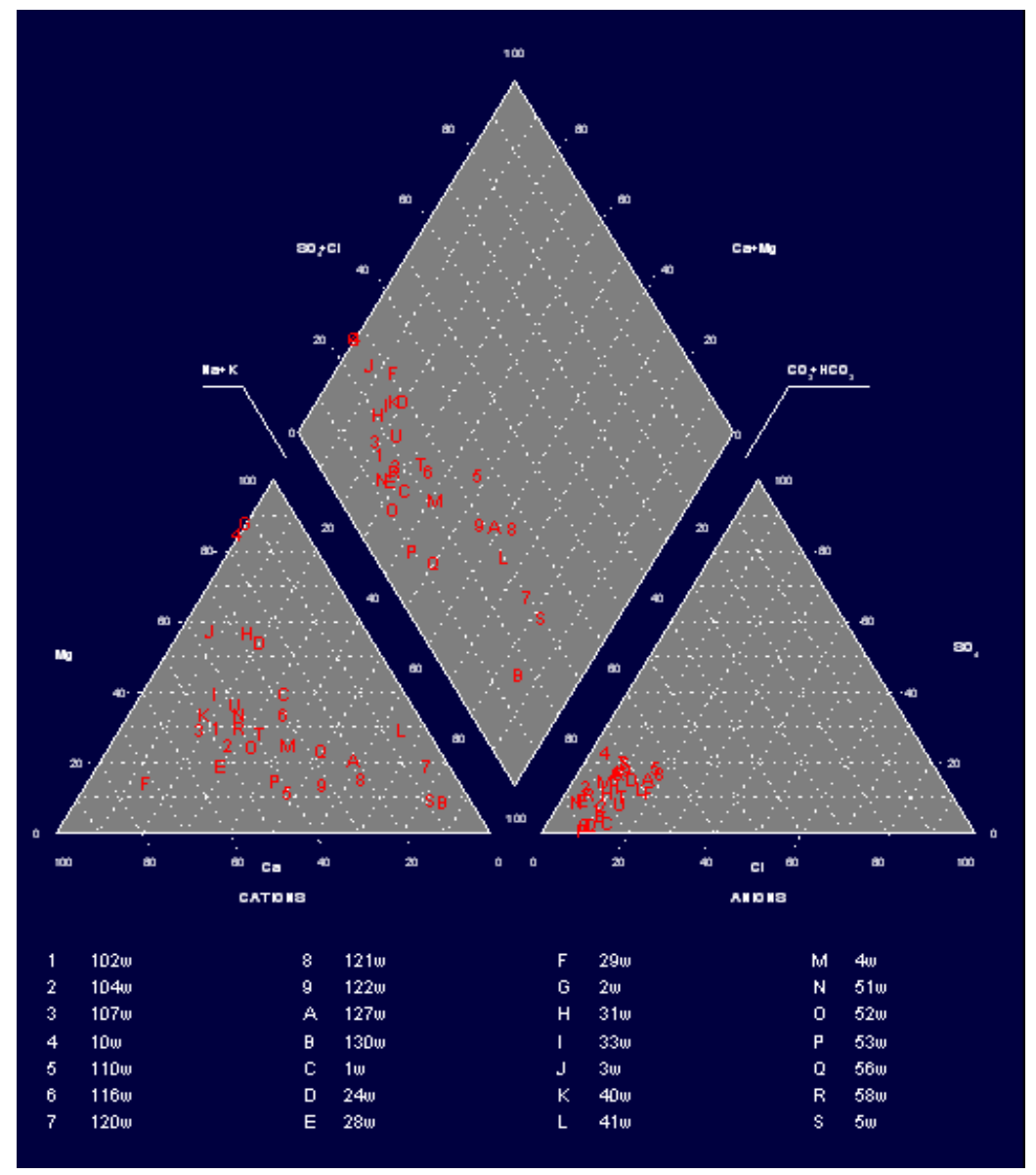

Figure 7: Bicarbonate water type, west side of the river.

\section{Conclusion}

According to the investigation and interpretation of the chemical results, the majority of water samples in the study area are dominated by bicarbonate water types. This bicarbonate water type is divided into three subgroups as sodiumpotassium bicarbonate type, calcium-magnesium bicarbonate water type and sodium-potassium-calcium-magnesium bicarbonate type. All groundwater 
samples were taken in the study area within the range of permissible limits for livestock, except for three water samples on the west side of the river which were very high bicarbonate (above the permissible limit $500 \mathrm{mg} / \mathrm{l}$ ). In addition, all groundwater samples were taken within the nitrogen component range as ammonia, nitrite and nitrate - this means there is no nitrogen pollution. In addition, all water samples vary from suitable to unsuitable for irrigation purposes while most of them are fit for human consumption.

\section{Acknowledgements}

First of all, my thanks and gratefulness are to Allah, for giving me the strength, patience and confidence to complete this work. Acknowledgements are also forwarded to the persons mentioned in this work and to many more in the list of references at the end for the assistance obtained.

\section{References}

[1] Lahmeyer International Feasibility Study for the Merowe Irrigation Project, Final Report, Annex 2.2, Groundwater investigations; Khartoum -Sudan (Feb. 2006).

[2] Groundwater and Wadis Directorate \& International Atomic Energy Agency: The Use of Isotopes for Evaluation of Groundwater Resources, Khartoum-Sudan (Nov. 2000).

[3] Bonfica Geoexpert: Main Report, Details Studies of El Seleim - KhowiQaab Area; Rpma- Italy (1986a).

[4] Bonfica Geoexpert): Details Studies of El Seleim - Khowi- Qaab Area; the River Nile, Annex D, Rpma- Italy (1986b).

[5] Salih, Lh. M: EL Seleim - Reappraisal of the Northern and Nile Province Pump Schemes: (1987).

[6] American Public Health Association, Standard Methods for the Examination of Water and Seawater $12^{\text {th }}$ edition New York (1965).

[7] American Public Health Association, (APHA): Standard Methods for the Examination of Water and Seawater - New York (1988).

[8] Andrew. G.,): The Geology of Sudan, in Tothil, G.D (Ed). Agriculture in the Sudan, Oxford University - London (1948).

[9] Brown, Lemay, and Buster): Chemistry of Water: the Central Science, 7th ed. Upper Saddle River, NJ: Prentice Hall (1997).

[10] Hem, J.D,: Study and Interpretation of Chemical Characteristics of Natural Water, second addition. U.S. Geology Survey Water Supply Paper 1473. US Department of the Interior, Washington DC (1970).

[11] Ibrahim M. E. Re-Evaluation of El Seleim Area Groundwater Resources, MSc University of London (1985). 